\title{
Analysis of the Influence of Intellectual Capital Use Efficiency on National Competitiveness Growth
}

\author{
Yulia Andreevna Bukhanova
}

Russian Scientific Research Institute of Economics, Politics and Law in Science and Technology

E-mail: juntu@ya.ru

\section{Irina Evgenievna llina}

Russian Scientific Research Institute of Economics, Politics and Law in Science and Technology

E-mail: skvo_ie@mail.ru

\section{Svetlana Evgenievna Ushakova}

Russian Scientific Research Institute of Economics, Politics and Law in Science and Technology E-mail: svetlanaush804@yandex.ru

\section{Elena Nikolaevna Zharova}

Russian Scientific Research Institute of Economics, Politics and Law in Science and Technology E-mail: zharovaen@rambler.ru

Doi:10.5901/mjss.2015.v6n6s2p420

\section{Abstract}

Aim. The aim of the study is to reveal the relationship between the level of effectiveness of national intellectual capital use and the level of national competitiveness and to detect if there is a difference in the character of the relationship in developed and developing countries. In the article the description of national intellectual capital and its components is presented. The character of the relationship between the indicators that reflect the level of intellectual capital development and the efficiency of its use and one of the macroeconomic indicators of national competitiveness - the national labor productivity, expressed in gross domestic product (GDP) per person employed, - is examined. Method. The analysis of the influence of country's intellectual capital and the efficiency of its use on the national competitiveness increase was performed by the method of correlation-regression analysis as the most suitable for this for this purpose. The study was conducted on a sample of 215 countries and their indicators on the basis of their assignment to the groups depending on income level. Results. The study has confirmed the dependence of the target indicator of country's labor productivity, expressed in GDP per person employed on the indicators of the efficiency of intellectual capital use. The belonging of a country to one or another income group does not affect the nature of the relationship between the level of national competitiveness and the level of indicators which characterize the efficiency of intellectual capital use. Conclusion. To develop an effective set of measures to improve the efficiency of national intellectual capital use it is advisable to consider not only the experience of countries which belong to the group of high income level, but also the experience of countries from other groups, for example, the experience of rapidly developing countries from upper middle and middle groups such as China, Brazil, India.

Keywords: intellectual capital, national competitiveness, macroeconomic indicators, research and development

\section{Introduction}

Reindustrialization of the economy, including modernization of the domestic industry based on innovation, is impossible without the active use of intellectual capital. The concept of intellectual capital finds its application at the micro-, mesoand macroeconomic level. At the mesoeconomic level, this category is the aggregate of intellectual capital of an industry or a region of a country, at the macroeconomic level it is the aggregate of intellectual capital of a country as a whole.

At the present stage of socio-economic development of the world economy and the economies of countries intellectual capital acquired a special importance as one of the factors of production which have an impact on economic growth. To a great extent the welfare of the country depends on the level of development of country's intellectual capital 
and the effectiveness of its use in the country's economy. Indicators that reflect the level of development of intellectual capital and the effectiveness of its use are, for example, the share of high technology products in gross domestic product (GDP), share of export of high technology products in GDP, indicators of scientific publication activity, the level of patent activity in the country, number of researches, employment in research and development (R\&D). The aim of the study is to reveal the relationship between the level of effectiveness of national intellectual capital use which is expressed in the indicators mentioned above and the level of national competitiveness and to find out if there are differences in the character of this relationship in developed and developing countries.

\section{Literature Review}

The conception of intellectual capital is the subject of wide discussion today. This theme is developed in the works of scientists engaged in the research of formation and use of intellectual capital, such as G. Becker, W. Bowen, J. BenPorat, G. Mintzer, L. Thurow, T. Schultz, L. Edvinsson, M. Malone, N. Bontis and a number of other researchers, who point out that knowledge and skills have socio-economic value. They, in turn, rely on the works of classics of political economy: David Ricardo, William Petty, Adam Smith, who analyzed the nature of the workforce, considered the creative abilities of people and their development as the main source of wealth of the country. L. Edvinsson and M. Malone note that at the microeconomic level, the intellectual capital generated by human knowledge, is the hidden source of the company's value (Edvinsson, Malone, 1997). T. Stewart defines intellectual capital as an intellectual material that includes the knowledge, experience, information, intellectual property, and participates in the creation of value (Stewart, 1997).

At the macroeconomic level intellectual capital consists of two components. The first component is the human capital of a country - people with their abilities, skills, knowledge and qualifications. People are national labor resources on the qualitative characteristics of which depends the quality of functioning of the economic system, economic growth, and hence the welfare of the society. The second component is a "derivative of human capital" - intellectual property, or in other words intellectual product. The category of intellectual product includes "...inventions, discoveries, patents, scientific reports and papers, projects, descriptions of technologies..." (Raizberg, Lozovsky, Starodubtseva, 1999). As noted by researchers S.E. Ushakova and S.S. Aushkap: "There are many areas of implementation of intellectual product. Intellectual product is used in the economic activity of enterprises, in the education system, as well as a source of the accumulation of basic knowledge that can be claimed in the future."(Ushakova, Aushkap, 2014). According to D.V. Grigoriev: "The intellectual capital of the society is a new, complex multifactorial concept, which includes everything related to information and human resources that fully explains the growing popularity of this topic among economists worldwide (Grigoriev, 2009). It should be noted that in modern conditions the use of intellectual capital becomes the keystone to sustainable economic growth and national competitiveness increase.

The concept of national competitiveness is closely related to the level of productivity of the economy's resources. M. Deryabina and S. Kolchin define national competitiveness as "... the ability of the national economy in market system to produce and consume goods and services in a competitive environment with the goods and services produced in other countries." (Deryabina, Kolchin, 2005). In general terms, national competitiveness is defined as a country's ability to achieve high parameters of economic development in comparison with the competing countries and sustain these parameters at a high level, with a tendency to increase them in the medium and long term period of time. These parameters are, for example, the country's GDP, the rate of GDP growth, labor productivity, expressed in GDP per person employed. The parameters of economic development mentioned above can serve as target indicators, which reflect the efficiency of intellectual capital use for the purposes of national competitiveness increase. For this research the indicator of labor productivity, expressed in GDP per person employed was chosen.

\section{Research Methods}

To analyze the influence of efficiency of intellectual capital use on national competitiveness increase the tools regressioncorrelation analysis were used. This method allows to reveal the relationship between the efficiency of the use of intellectual capital and the rate of increase of competitiveness of the country. The statistical data of the World Bank, the World Intellectual Property Organization, The Global Innovation Index 2014, SCImago Journal \& Country Rank on 215 countries was analyzed. As mentioned above the target indicator, which reflects the growth of the country's competitiveness - GDP per person employed - was chosen. As explanatory variables of the model, reflecting the level of use of intellectual capital, 16 indicators presented in Table 1, were selected. The variables are arranged in the following groups: publication activity, expenditures on R\&D and education, employment in R\&D, patent activity, income from 
intellectual property use. The values of the explanatory variables were taken mainly as of 2011 . As there is a time lag in the impact of explanatory variables on the dependent value of national labor productivity expressed in GDP per person employed, the dependent value is taken as of 2012. In our opinion, the time lag of one year is sufficient for the analysis of the influence of efficiency of intellectual capital use on the target macroeconomic indicators of economic development due to the fact that science and technology evolve more or less uniformly over time, without any sharp spurts.

Table 1. Variables of the regression-correlation model which presents the dependence of labor productivity on the efficiency of the intellectual capital use.

\begin{tabular}{|c|c|c|}
\hline Name of Variables & Description of Variables & Data Source \\
\hline \multicolumn{3}{|c|}{ Dependent Variable: } \\
\hline producivity-12 & $\begin{array}{l}\text { Labor productivity (GDP per person employed in US } \\
\text { dollars) }\end{array}$ & The World Bank http://data.worldbank.org/ \\
\hline \multicolumn{3}{|c|}{ Explanatory Variables: } \\
\hline \multicolumn{3}{|c|}{ Group 1:Publication Activity } \\
\hline articles & Number of scientific and technical articles in journals & $\begin{array}{l}\text { Global Innovation Report } 2014 \\
\text { https://www.globalinnovationindex.org/ }\end{array}$ \\
\hline citation & Number of citations per article & $\begin{array}{l}\text { Scimago Journal \& Country Rank } \\
\text { http://www.scimagojr.com/ }\end{array}$ \\
\hline documents & Total number of documents (all types) & $\begin{array}{l}\text { Scimago Journal \& Country Rank } \\
\text { http://www.scimagojr.com/ }\end{array}$ \\
\hline h-index & $\begin{array}{l}\text { Country's number of articles ( } h \text { ) that have received at } \\
\text { least } h \text { citations }\end{array}$ & $\begin{array}{l}\text { Scimago Journal \& Country Rank } \\
\text { http://www.scimagojr.com/ }\end{array}$ \\
\hline \multicolumn{3}{|c|}{ Group 2: Expenditures on R\&D and education } \\
\hline expenditure & R\&D expenditure (\% of GDP) & The World Bank http://data.worldbank.org/ \\
\hline $\begin{array}{l}\text { exp-education-of- } \\
\text { all }\end{array}$ & $\begin{array}{l}\text { Government expenditures on education (\% of total } \\
\text { government expenditures) }\end{array}$ & The World Bank http://data.worldbank.org/ \\
\hline $\begin{array}{l}\text { exp-education-of- } \\
\text { gdp }\end{array}$ & Government expenditures on education (\% of GDP) & The World Bank http://data.worldbank.org/ \\
\hline \multicolumn{3}{|c|}{ Group 3: Employment in R\&D } \\
\hline employment & Employment in R\&D (\% of total employment) & $\begin{array}{l}\text { Global Innovation Report } 2014 \\
\text { https://www.globalinnovationindex.org/ }\end{array}$ \\
\hline researchers & Number of researchers in R\&D (per million people) & The World Bank http://data.worldbank.org/ \\
\hline \multicolumn{3}{|c|}{ Group 4: Patent activity } \\
\hline patent & Patent applications, residents & $\begin{array}{l}\text { World Intellectual Property Organization } \\
\text { http://www.wipo.int/ipstats/ }\end{array}$ \\
\hline patent_per_pop & Resident applications per million population (by origin) & $\begin{array}{l}\text { World Intellectual Property Organization } \\
\text { http://www.wipo.int/ipstats/ }\end{array}$ \\
\hline total-utility-model & Total utility model applications, residents & $\begin{array}{l}\text { World Intellectual Property Organization } \\
\text { http://www.wipo.int/ipstats/ }\end{array}$ \\
\hline trademark & Trademark applications, residents & $\begin{array}{l}\text { World Intellectual Property Organization } \\
\text { http://www.wipo.int/ipstats/ }\end{array}$ \\
\hline \multicolumn{3}{|c|}{ Group 5: Income from intellectual property use } \\
\hline payment_for_ip & Charges for the use of intellectual property, payments & The World Bank http://data.worldbank.org/ \\
\hline receipts_for_ip & Charges for the use of intellectual property, receipts & The World Bank http://data.worldbank.org/ \\
\hline royalty & Royalties and license fees, payments (\% of total trade) & $\begin{array}{l}\text { Global Innovation Report } 2014 \\
\text { https://www.globalinnovationindex.org/ }\end{array}$ \\
\hline
\end{tabular}

In order to assess whether the degree of impact of intellectual capital use efficiency varies depending upon the belonging of a country to the category of developed or developing countries, dummy variables that take the value 0 or 1 , depending on whether they belong to one group or another, were included into the model. All countries included in the sample were classified into one of four groups according to the classification of the World Bank: countries with high income, countries with upper middle income, countries with middle income and countries with low income. As a result the analysis of dependence of the dependent variable on the explanatory variables was based on this classification. The analysis showed that the dummy variables are not significant in the model. Therefore the character of relationship between the dependent variable and explanatory variables does not depend on the fact if a country belongs to one group or another. Correlation analysis showed the following results which are presented in Table 2. 
Table 2. Correlation between the dependent variable (GDP per person employed) and explanatory variables which characterize the efficiency of intellectual capital use

\begin{tabular}{|l|c|}
\hline Explanatory Variables & Correlation Rate \\
\hline citation & $\mathbf{0 , 8 7}$ \\
\hline expenditure & $\mathbf{0 , 8 1}$ \\
\hline researches & 0,75 \\
\hline h_index & 0,73 \\
\hline employment & 0,62 \\
\hline articles & 0,59 \\
\hline documents & 0,59 \\
\hline payment_for_ip & 0,51 \\
\hline trademark & 0,50 \\
\hline receipts_for_ip & 0,48 \\
\hline patent_per_pop & 0,48 \\
\hline exp_education_of_gdp & 0,32 \\
\hline royalty & 0,30 \\
\hline patent & 0,27 \\
\hline total_utility_model & 0,10 \\
\hline exp_education_of_all & $-0,19$ \\
\hline
\end{tabular}

The closest positive correlation is found between the labor productivity and the explanatory variables such as the number of citations per article, R\&D expenditure (\% of in GDP), number of researchers in R\&D, h-index. In general, the correlation between the dependent and explanatory variables is positive for all indicators except the indicator government expenditures on education (\% of total government expenditures). According to calculation such indicators as government expenditures on education (\% of GDP), royalties and license fees, patent applications, total utility model applications have low correlation with national labor productivity.

In the process of analyzing of the influence of intellectual capital use efficiency on the national competitiveness the average values of the explanatory indicators for each group of countries by income level according to World Bank classification have been calculated (Table 3). Analysis generally confirmed that in high-income countries the indicators of intellectual capital use are higher than in other countries. The values of indicators decrease with the decreasing of countries' income in the analyzed sample.

Table 3. Average values of the explanatory variables for each group of countries by income level according to World Bank classification.

\begin{tabular}{|l|c|c|c|c|}
\hline Name of Variables & High Income Countries & Upper Middle Income Countries & Middle Income Countries & Low Income Countries \\
\hline producivity-12 & 38390,92 & 17515,45 & 10395,72 & 2557,17 \\
\hline articles & 6999,81 & 2761,01 & 693,89 & 33,48 \\
\hline citation & 4,82 & 3,43 & 3,83 & 4,56 \\
\hline documents & 29494,97 & 12533,13 & 3648,47 & 250,93 \\
\hline h-index & 266,16 & 95,21 & 74,87 & 51,48 \\
\hline expenditure & 1,63 & 0,56 & 0,28 & 0,12 \\
\hline exp-education-of-all & 13,02 & 14,57 & 15,61 & 15,72 \\
\hline exp-education-of-gdp & 4,99 & 4,47 & 4,83 & 3,76 \\
\hline employment & 37,36 & 21,65 & 15,18 & 5,49 \\
\hline researchers & 3450,75 & 784,28 & 465,18 & 42,40 \\
\hline patent_ & 17,89 & 15,36 & 0,61 & 2,00 \\
\hline patent_per_pop & 449,43 & 36,78 & 13,62 & 3,00 \\
\hline total-utility-model & 3062,15 & 35047,29 & 1183,40 & 2,00 \\
\hline trademark & 19838,66 & 55342,71 & 15078,39 & 723,50 \\
\hline payment_for_ip & 4257,36 & 695,88 & 198,75 & 5,12 \\
\hline receipts_for_ip & 5414,83 & 75,09 & 27,01 & 5,16 \\
\hline royalty & 1,59 & 0,43 & 0,40 & 0,11 \\
\hline
\end{tabular}

In the process of modelling different combinations of explanatory variables shown in Table 1 were tested. To eliminate 
heteroscedasticity the interdependent variables, such as the number of citations per article and h-index, or patent applications and resident applications per million population, were not included in the regression model simultaneously. Furthermore, in the process of modelling, it was concluded that the optimal number of variables for the model is 3 or 4 . This is due to the problem of lack of some observations for some variables. That is why the amount of 3 or 4 variables in the model are optimal to build a plausible model. In table 4 the model with the highest coefficient of determination is presented. In this model the explanatory variables are: the employment in R\&D (\% of total employment), the indicator of publication activity - h-index and the indicator of patent activity - resident applications per million population (by origin). This model confirms the close relationship between the dependent variable and the explanatory variables.

Table 4. Regression model of the dependence of national labor productivity on the indicators of the efficiency of intellectual capital use.

\begin{tabular}{|c|c|c|c|c|}
\hline \multicolumn{5}{|c|}{ Dependent Variable: log(productivity 12) } \\
\hline \multicolumn{5}{|c|}{ Method: Least Squares } \\
\hline \multicolumn{5}{|c|}{ Sample (adjusted): 2206} \\
\hline \multicolumn{5}{|c|}{ Included observations: 66 after adjustments } \\
\hline Variable & Coefficient & Std. Error & t-Statistic & Prob. \\
\hline c & 8.446493 & 0.297194 & 28.42079 & 0.0000 \\
\hline employment & 0.019163 & 0.004643 & 4.127435 & 0.0001 \\
\hline $\log (\mathrm{h}$ index $)$ & 0.131087 & 0.064363 & 2.036672 & 0.0460 \\
\hline log(patent_per_pop) & 0.105707 & 0.034493 & 3.064625 & 0.0032 \\
\hline \multicolumn{3}{|l|}{ R-squared } & & \\
\hline Adjusted R-squared & 0.714352 & \multicolumn{2}{|c|}{ Mean dependent var } & 10.17588 \\
\hline S.E. of regression & 0.302244 & \multicolumn{2}{|c|}{ S.D. dependent var } & 0.565512 \\
\hline Sum squared resid & 5.663778 & \multicolumn{2}{|c|}{ Akaike info criterion } & 0.503526 \\
\hline Log likelihood & -12.61634 & \multicolumn{2}{|c|}{ Schwarz criterion } & 0.636232 \\
\hline F-statistic & 55.18434 & \multirow{2}{*}{\multicolumn{2}{|c|}{ Hannan-Quinn criter. }} & 0.555964 \\
\hline Prob(F-statistic) & 0.000000 & & & 1.960440 \\
\hline
\end{tabular}

The final equation describing the model is as follows:

$\log \left(\right.$ productivity_12) $=8.446+0.01916^{*}$ employment $+0.13108^{*} \log (h$ index $)+0.1057^{*} \log$ (patent_per_pop), (1)

The data from the table 4 shows that all variables are significant at the $5 \%$ significance level, indicating the correctness of the model. With the growth of employment in R\&D by 1 unit national labor productivity increases by 1.9\%, with other statements of the problem being equal. With the growth of $h$-index by $10 \%$ national labor productivity increases by $1.3 \%$, with other statements of the problem being equal, and with the growth of patent activity by $10 \%$ national labor productivity increases by $1.01 \%$. The figure 1 below describes the model of dependence of national labor productivity on the indicators of the efficiency of intellectual capital use.

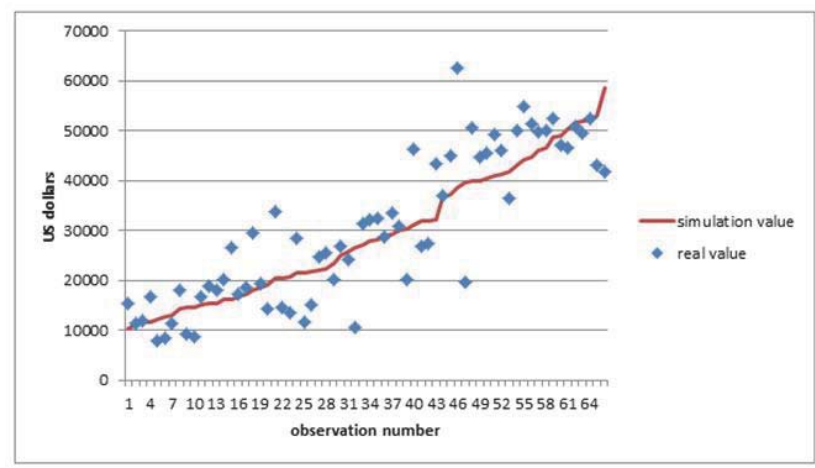

Figure 1. The graphic presentation of the model of dependence of national labor productivity on the indicators of the efficiency of intellectual capital use (Equation 1). 


\section{Analysis Result}

The regression-correlation analysis confirmed the dependence of the target indicator of national labor productivity, expressed in GDP per person employed, on the indicators of the efficiency of intellectual capital use. Moreover, the level of correlation between the dependent and explanatory variables for some indicators, characterizing the level of intellectual capital development and the efficiency of its use, is quite high. High correlation coefficient is obtained on such indicators of the level of development and use of intellectual capital as citation, R\&D expenditures, number of researchers in R\&D, h-index, employment in R\&D. However, for some variables the dependence is not obvious, the correlation coefficient is low; moreover, for the government expenditures on education (\% of total government expenditures) the correlation coefficient is negative. Nevertheless, rather high correlation coefficient for the most part of the indicators gives reason to claim that the level of contribution of intellectual capital to the welfare of a country and its competitiveness is high. On the basis of obtained results it can be confirmed that the effectiveness of intellectual capital use has a direct influence on the growth of national competitiveness.

\section{Conclusions}

The study showed that there is a direct correlation between the level of development of intellectual capital and the growth of main macroeconomic indicators characterizing the level of national competitiveness. In addition, the calculations have confirmed the hypothesis that in countries with high income the indicators of the effectiveness of intellectual capital use are higher as a whole. However, the belonging of a country to one or another income group according to the World Bank classification does not affect the nature of the relationship between the dependent variable, which characterizes the level of national competitiveness, and the explanatory variables - indicators of the level of intellectual capital development and efficiency of its use. In this context, to develop an effective set of measures to improve the efficiency of national intellectual capital use it is advisable to consider not only the experience of countries from the group with high level of income, but also the experience of countries from other groups, for example, the experience of such rapidly developing countries as China, Brazil, India.

\section{References}

Deryabina M., Kolchin S. (2005). The Competitiveness of the Russian Economy in the Context of Globalization // Power, 2, pp. 43. Edvinsson L., Malone M.S. (1997). Intellectual Capital. Piatkus. London.

Grigoriev D.V. (2009), Intellectual capital: from the Level of the Individual to the Level of the Society // Problems of Modern Economics, $3(31)$.

Raizberg B.A., Lozovskiy L.S., Starodubtseva E.B. (1999). Modern Dictionary of Economics. - 2nd ed., Rev. M.: INFRA-M.

Stewart T. (1997). Intellectual Capital: The New Wealth of Organizations. Nicholas Brealey Publishing. Business Digest. New York.

Ushakova S.E., Aushkap S.S. (2014). Problems of Demand for Intellectual Products of the Sphere of High Technologies in the Russian Federation, Vector of Science of Togliatti State University, Series: Economics and Management, 2(17). 